\title{
Dangerous neighbours: sorcery, conspicuous exchange and proximity among urban migrants in northern Mozambique
}

\author{
Christian Laheij
}

\section{Introduction}

It was approaching dusk when I heard people shouting on the street outside my house in Bairro Acordado. ${ }^{1}$ Situated in northern Mozambique, I had been living and doing fieldwork in this neighbourhood of Nampula City for several months, and I went outside to see what was going on. I was surprised to find my next-door neighbour Ali embroiled in a heated exchange of words with Roxana, the neighbour from across the road. Normally a soft-spoken youth of eighteen years old, Ali trembled with fury as he stood in the middle of the street with a crowd gathering around him. Roxana had just called him havara, which translates from eMakhuwa as leopard but also refers to a type of sorcerer ${ }^{2}$ who causes discord and unhappiness. In response, Ali now pointed at Roxana and called her ekuluwe, eMakhuwa for pig. The thirty-three-year-old woman hooted with derision. If she were a pig, she retorted to laughter and cheers from the onlookers, Ali's father must love pigs, because he wanted to sleep with her. It was then that Ali's stepmother Rajah intervened. She rushed out from her yard and pulled her stepson away, telling him to stay quiet as they disappeared inside.

It was a remarkable incident. When I enquired the next day, it turned out that tensions had been brewing for some time between the two households. This had started after Roxana had prohibited her nine-year-old son Gerónimo from going over to Rajah's house. He used to eat lunch there on a regular basis. For Rajah and her family, it had been their way of helping out a neighbour who, unemployed and a single mother of seven, struggled to get by. Such arrangements were not uncommon in Bairro Acordado, especially among second-generation urban migrants such as Roxana and Rajah who knew each other well. Nor was it unusual that they led to disputes and recriminations, including allegations of sorcery; in the case of Roxana, who had at first encouraged her son to visit

Christian Laheij is a research fellow at the Max Planck Institute for Social Anthropology in Halle/ Saale, Germany. He received his PhD from the London School of Economics and Political Science (2015). His current research focuses on new religious movements, infrastructure and experiences of precarity in the post-socialist extractive economy of northern Mozambique. Email: laheij@eth. mpg.de

${ }^{1}$ The names of locations and people have been changed in this article in order to protect the anonymity of research participants.

${ }^{2}$ Following the distinction first made by Evans-Pritchard (1937), the different types of sorcery mentioned in this article could be classified as witchcraft, involving unconscious and inborn psychic powers, and sorcery, which consists of the conscious use of tools. While people in Nampula City do distinguish between the two different mechanisms underlying this classification, they use the same word, enretthe in eMakhuwa, and tend to emphasize practitioners' conscious state of mind. I therefore translate enretthe as sorcery, in line with Kottak (2002: 137-44).

(C) International African Institute 2018 
Rajah, she put a stop to it when she found out that Rajah's children allegedly bullied him, which she interpreted as a sign of sorcerous intent. What was exceptional, however, was that these recriminations were voiced in public.

In general, direct confrontations between neighbours were rare in Bairro Acordado. Roxana herself once told me that it was dangerous to be seen to cause upset to others. 'You have to be very careful,' she said. 'There are many sorcerers in this area, and they take advantage of that kind of situation. They throw a curse and if the upset person dies, the blame will fall on you.' Rajah agreed. She had pulled Ali inside, she related to me, because she was afraid of what might happen if the exchange of words continued. Indeed, in the weeks following the argument, both women made a point of greeting each other ostentatiously when their paths crossed on the street, thus conveying that everything had reverted back to normal.

The argument between Roxana's and Rajah's households captures a sentiment shared by many in Bairro Acordado: namely, that life in Nampula City is hard, and that, in this context, relations with neighbours are difficult to navigate and fraught with danger, uncertainty and risk. In this article, I further contextualize this sentiment as a window into urban experiences of proximity, and the particular demands these place upon urban migrants in terms of managing and negotiating their relatedness. My analysis is guided by a hypothesis formulated by J. Clyde Mitchell (1965) on the basis of fieldwork conducted in the 1950s in what is now Harare. Mitchell observed about African urban communities that these are fundamentally different from villages in terms of their internal composition and social structure. Whereas villages tend to be clustered around relatively stable and homogeneous kin groups, city dwellers live among strangers on whom they do not depend for future cooperation. This difference has consequences for the salience of sorcery fears in people's perceptions of misfortune. In villages, argued Mitchell, following the structural-functionalist theoretical framework that was dominant in British anthropology at the time, sorcery discourses function to alleviate social tensions and facilitate segmentation. They provide people with a means to attack their rivals in an environment where hostility cannot be expressed otherwise. Social separation in cities implies that it is easier to express frustrations openly and break off social ties there. There is less need to couch animosity in supernatural terms, and for this reason, Mitchell predicted, urban life would see a decline in explanations of misfortune with reference to sorcery.

I seek to expand on this prediction below. I argue that while Mitchell's hypothesis about the decrease in sorcery fears in African cities is contradicted by their prevalence in Nampula City, his focus on questions of proximity offers a valuable contribution to more recent theoretical propositions that equate sorcery discourses with modernity's discontents. As I will show, the impact of modernity is mediated by considerations of social and physical distance of the sort highlighted by Mitchell, and it is precisely in relation to shifts in the balance between these considerations that sorcery fears in Bairro Acordado surface. In what follows, I first situate sorcery fears concerning neighbours in Bairro Acordado in relation to Makhuwa notions of kinship and show that these are related to similar anxieties about sorcery threats posed by kin residing in the countryside. I then illustrate my analysis with a discussion of the life histories of Roxana and Rajah, and explore how notions of sorcery were implicated in the dispute between their households. The article concludes with a discussion of 
the implications of my findings for anthropological theories of sorcery, misfortune and urban migration.

\section{Modernity, proximity and sorcery fears}

Bairro Acordado, the neighbourhood where Roxana and Rajah live, has a population of more than 50,000 residents, making it one of Nampula City's larger neighbourhoods. Almost all inhabitants are Makhuwa, the predominant ethnic group in northern Mozambique, and the majority are urban migrants. If this makes for a degree of homogeneity, Bairro Acordado's population is diverse in other terms. People of different means live cheek by jowl; levels of education vary; and while 46 per cent of residents are Muslim, 40 per cent are Catholic, with the remainder either classified as Protestant or as having no or a different religion (INE 2007). This diversity has its roots in the neighbourhood's turbulent colonial and postcolonial past. In the 1960s, when the Portuguese administration earmarked the then sparsely populated area of Bairro Acordado for urban expansion, only those with formal employment were allowed to construct their houses there. Such restrictions were lifted after the socialist independence movement FRELIMO took over from the Portuguese in 1975. With urban migrants flocking to the city in search of a better life, the neighbourhood grew rapidly. In the 1980s and early 1990s, civil war with the guerrilla movement RENAMO, food shortages and structural adjustment programmes implemented by FRELIMO at the behest of the International Monetary Fund (IMF), World Bank and other international donors brought about displacement, destitution and a further influx of people from the countryside (Dinerman 2006; Geffray and Pedersen 1986; Wilson 1992). The General Peace Accords of 1992 and subsequent democratization of Mozambique have since paved the way for economic recovery and a boom in foreign investment, which mainly benefit a small elite (Archambault 2012; Hanlon and Smart 2008; Pitcher 1996; Sumich 2015). This has prompted the latest wave of new arrivals to the neighbourhood: young families who prefer the low rents of refurbished houses in Bairro Acordado to the expense and cramped conditions of apartments in the city centre.

One does not have to look far in Bairro Acordado to realize that Mitchell's prediction about the demise of sorcery fears in urban contexts does not apply. Inhabitants readily describe the city as an environment where they are particularly vulnerable to sorcery attacks, and conversations are replete with references to sorcery. In some cases, these indicate a general climate of distrust, suspicion and uncertainty (cf. Lienhardt 1951). For example, people warn each other that unnamed sorcerers collect nail clippings, hair or footprints to inflict curses, or that they use the cover of the crowd to attack at the market. There are rumours of bloodsuckers (chupa-sangues) roaming the neighbourhood with advanced blood transfusion machines to target residents in their sleep, while another type of sorcerer called mwawelo is reputed to dance naked outside people's houses at night, stealing their money. Victims wake up the next morning and find the money where they left it but spend it rashly - the mwawelo has stolen the value of the money, but not its material form. At other times, narratives of sorcery are more specific. This happens when wealthy couples in the neighbourhood are 
rumoured to engage genies (majini) or giant snakes (víbora) to go out and steal for them. In return for their services, the couples let the creatures sleep with the wife and feed on her blood. Similarly, married women fear that single women in their surroundings use love potions to lure away their husbands and cause marital disagreement, just as better-off residents blame misfortune in their lives on the ill will and jealousy of those around them. Even in those cases, however, accusations are rarely expressed directly or publicly. Rather, people voice suspicions in private, and prefer temporary avoidance over confrontation.

What stands out from these diverse articulations and anxieties is their concern with social inequality, money, accumulation, technology and other indices of modern lifestyles. This tallies with a common finding in the Africanist anthropological literature of the past two decades: namely, that sorcery discourses and practices are distinctly 'modern' phenomena that thrive in settings where urbanization, commoditization, democratization and other processes associated with modernity uproot existing life worlds. Jean and John Comaroff (1993) and Peter Geschiere (1997) were among the first to highlight this mutual implication. They showed that in present-day Africa occult threats are not only modern in terms of the imaginaries used for their representation. Crucially, they are also constitutive of modernity; they are what Todd Sanders (1999: 128) calls 'a metacommentary on the deeply ambivalent project of modernity'. This finding has since been specified and elaborated upon in contexts across the African continent, including, to name but a few examples, with reference to modalities of insecurity and state building in South Africa (Ashforth 2005; Niehaus 2005), neoliberalism in Tanzania (Sanders 2008), religious transformation in Ghana (Meyer 1999), Nigeria (Smith 2001) and Niger (Masquelier 2008), and modern communication technologies in West and Central Africa (Bonhomme 2012). For the Mozambican context, Harry West (2005) has argued that an upward trend in long-standing sorcery fears among Makonde residents of the Mueda Plateau in the 1990s was related to neoliberal reforms and the introduction of democracy, partly because of the deleterious effects these had on socio-economic equality, but also because commitments to liberal notions of individual freedom and human rights prevented local administrators from acting on sorcery accusations. ${ }^{3}$ Writing about perceptions of sorcery in Chimoio in Central Mozambique, Bjørn Enge Bertelsen (2016) similarly points to the articulation of processes of state formation with prevalent forms of sociality, but emphasizes the role of institutionalized forms of violence in sustaining and reconfiguring sorcery fears (see also Obarrio 2014).

Such varied entanglements with modernity suggest that it is unlikely that sorcery discourses will be rendered obsolete in cities, as Mitchell hypothesized. Instead, they multiply; for it is in cities that the impact of global socio-economic and cultural forces is felt most intensely. I find such an analysis compelling, to the

\footnotetext{
${ }^{3}$ In a separate volume on his fieldwork among the Makonde, West (2007) also reflects on the epistemological difficulties he encountered in studying sorcery ethnographically. This links with a strand of scholarship on the occult concerned with philosophical questions of rationality, knowledge, belief, uncertainty and doubt (see, for example, Bubandt 2014; Evans-Pritchard 1937; Kapferer 2003). I do not address these questions in the present article, as the focus is on broadly sociological concerns relating to the intersection of sorcery fears with social and historical change (cf. Sanders 2016).
} 
extent that it contextualizes sorcery and places it in relation to historical transformations. However, there is a risk that the emphasis on large-scale developments structuring sorcery fears comes at the expense of considerations of the type identified by Mitchell: namely, those relating to kinship and otherness. My point is not that the two sets of factors operate at different levels, and that it is often unclear in analyses of witchcraft and sorcery how the macro-level of global change is linked to the micro-level of everyday interaction (Sanders 2003; see also Englund and Leach 2000). Nor is it the aim of this article to reassert that kinship plays a central role in mediating fears and critiques of modernity (Englund 1996), or that it can be creatively reworked and adapted to order social relations in the face of migration and globalization, which is a key observation in Geschiere's (2013) recent proposal to reinstate kinship at the heart of the study of witchcraft, and one that certainly applies to the context of sorcery fears in Bairro Acordado. Rather, I seek to tease out Mitchell's distinction between two different kinds of proximity: social and physical. At least in the case of northern Mozambique, this distinction matters when it comes to sorcery, albeit in a more fluid way than Mitchell suggested.

In order to substantiate this claim, it is necessary to outline the relational notion of personhood that informs the perceptions of sorcery in Bairro Acordado noted above. The appropriate eMakhuwa term is okhalana. It means 'being with' and conveys a sense of togetherness according to which individual well-being is mediated by a person's relationships with others. As Elia Ciscato (2012: 31) observes, okhalana expresses a feeling of 'being member rather than partner': 'not isolated, but in intimate association and communion with something that is larger'. Importantly, this feeling goes beyond the existential awareness that human beings are interdependent because they rely on each other for shelter, sustenance and protection. Rather, interdependence is conceptualized in terms of an invisible force called eruku. This eMakhuwa term is sometimes translated as 'shadow' or 'spirit' (cf. Mbwiliza 1991: 70), but I think it is better understood as 'vital substance'.

Based on my fieldwork, eruku has the following characteristics. First, springing from the uterine group (erukulu), ${ }^{4}$ it is not of a universal nature or drawn from a shared cosmic pool, but unique to each family as it nurtures its members across space and time, both during their worldly existence and beyond, when they live on as ancestral spirits (minepa). Secondly, eruku is distributed, automatically transmitting states of well-being from one relative to the next, with the uterine group functioning as a circuit. It can thereby be immaterial as well as material and embodied in form, as eruku both flows through the veins of kin and materializes in their possessions, food, money and other instantiations of well-being. Thirdly, it is limited in supply, meaning that its distribution, as Nicholas Kottak (2002: 206) describes for Makhuwa perceptions of fortune in general, is a zero-

\footnotetext{
${ }^{4}$ Part of the Bantu matrilineal belt of South-Central Africa, Makhuwa practice matriliny. Historically, this has meant that clans (mahimo) in northern Mozambique trace their origins through the female line to male founders. The clans are subdivided into lineages (maloko) of 400 to 1,000 people, and lineages consist in turn of uterine groups (irukulu) of 50 to 150 people. Such divisions are, due to political, socio-cultural and economic changes, no longer as relevant as they once were. However, I found in Bairro Acordado that matrilineal principles of descent continue to influence social organization among Makhuwa (cf. Laheij 2015).
} 
sum game. In this respect, participants in my research suggested that one gets ahead in life only at the expense of others, and that the accumulation of wealth by one member of the uterine group means that others have less of it.

Finally, apart from determining people's physical condition and their material wealth, access to eruku is essential to being a moral person. Without it, the heart becomes filled with destructive desires such as envy, selfishness and revenge, which may culminate in sorcery attacks. It is therefore critical that kin work together to redistribute individual fortune and maintain healthy family relations, for if they fail, they risk estrangement and inviting ever greater cycles of mutual destruction upon their kin group.

As is evident from this description of eruku, people define themselves and their well-being primarily in relation to matrilineal kin. Yet, okhalana also has implications for non-kin relations. Called amalapo in eMakhuwa, meaning both strangers and enemies, non-kin do not share the same vital substance. The distribution of eruku is consequently less of a concern, but, seeing that it is easily converted into bodily fluids such as blood, semen and sweat, or into food and objects, there is an understanding that it can be exchanged between members of different kin groups, which generates its own set of anxieties. These centre partly on the effects of transmission. For instance, mothers are warned not to have sex while their sons undergo initiation rites, because the exchange of blood involved will disrupt the healing process of the sons' circumcision wounds. More important in relation to sorcery, however, are fears about the possibility of appropriation implied in the transferable nature of eruku. People are afraid that non-kin will destroy them by capturing their well-being without reciprocation; this is reinforced by the notion that there is no in-built cap on selfishness in interactions between non-kin, unlike in the case of kin, where people's well-being and morality are co-dependent.

Neighbours are therefore particularly suspect. Their physical proximity means that materializations of eruku are within their reach, and they may try to take advantage of their closeness to try to seize these, with devastating consequences. A Makhuwa proverb recorded by Alexandre Valente de Matos (1982: 168) warns in this regard: 'Your neighbour is the one who can kill you' (Wàttamannaweno t'oniwiva).

Makhuwa have historically responded to these fears with a combination of institutionalized coping mechanisms, ranging from avoidance and regulation to generalized reciprocity (cf. Arnfred 2011; Ciscato 2012; Geffray 1990; Kottak 2002; Martinez 1989). In the city, where living conditions are simultaneously crowded and socially dispersed, the emphasis is on conspicuous exchange, as a means to contain the threat posed by neighbours. From dusk to dawn, there is a constant stream of people, goods and favours circulating between different households in Bairro Acordado. People request salt from the neighbour; a child is sent across the street to ask for a piece of burning charcoal, a knife, or some groceries; and neighbours keep an eye on each other's children, watch TV together, and use the fridge next door to keep drinking water cold. The proactive nature of these non-kin exchanges mimics kin reciprocity and people's treatment of guests. Here, Makhuwa go out of their way to accommodate strangers, offering them their best food, their mattress if they have one, and, in the past, also their wife for the night (cf. Kottak 2002: 187-8). In line with the research literature on hospitality (Candea and da Col 2012; Pitt-Rivers 1968), such gestures can 
be interpreted as functioning as protection against the dangers of exposure to the unknown. By sharing their vitality, hosts demonstrate their goodwill and contribute to their guests' well-being, in the hope, even implicitly, that their guests will be prevented from acting selfishly. Mutual assistance in Bairro Acordado can be similarly argued to constitute a deliberate means of creating interdependence where there is none, giving residents a measure of control over their social surroundings.

The problem facing Bairro Acordado's population of urban migrants, however, is that participation in these networks of assistance and exchange among neighbours does not always sit well with their obligations towards kin. While the two are not mutually exclusive, people's attempts to convert physical into social proximity by investing in relationships with strangers in their immediate surroundings carry the risk that they neglect kin in the countryside with whom, following the workings of eruku, they remain connected regardless of the physical distance. In other words, inhabitants of Bairro Acordado have to strike a balance between their desires to ward off sorcery attacks from neighbours by engaging them in relations of exchange and asserting their bonds of interdependence, and the need to prevent estrangement from kin through redistribution so as to ensure that no harm will come from that quarter.

Depending on personal circumstances, not everyone experiences this conundrum to the same degree, or in the same way. Yet, due to the aforementioned socio-economic changes of the past decades, and the deteriorating effects these have had on living standards and social equality, it is a dilemma that has become increasingly acute for neighbourhood residents. It is against this backdrop that I seek to draw attention to Mitchell's hypothesis regarding the prevalence of witchcraft and sorcery fears in African cities. In light of the above, a fundamental flaw in his hypothesis about sorcery's demise is the association of sorcery fears with situations in which social and physical proximity coincide: urban migrants would be less prone to experience misfortune in occult terms, Mitchell suggested, because they live away from their families, among strangers. This association does not apply to the case of Nampula City, where, as already outlined, sorcery fears surface instead in the interstices of the two kinds of proximity, and are most pronounced when the lack of overlap becomes manifest.

Nevertheless, with that qualification in mind, Mitchell's analysis raises an important point about the implication of global forces of production, transaction and consumption in fears of the occult. When people in Bairro Acordado make reference to these forces in their discourses of sorcery, they are not necessarily critical of modern lifestyles as such. Rather, they are referencing the specific difficulties they experience in managing their relatedness in the face of modernity, and the impact this has on their ability to live morally and in mutuality with both kin and strangers. There is a self-reinforcing dynamic at work, according to which experiences of poverty, insecurity and other instances of hardship make it difficult for people to bridge physical and social proximity, while simultaneously serving as evidence for their failure to succeed, thus intensifying sorcery fears. In the next two sections, I detail the respective life histories of Roxana and Rajah in order to illustrate how difficult it is to get out of this cycle. 


\section{Precarious living}

Roxana was one of the first people I met when I moved to Bairro Acordado in November 2010. A second-generation migrant, she lived in the house opposite the one I had rented in the neighbourhood. It was a house that spoke of destitution, decay and broken dreams. Decades ago, when it was built by her father, it had represented a promise of a brighter future, with its concrete walls, its fibrocement roof and its connections to the city's water and electricity networks. This was during colonial times, when Bairro Acordado had been an up-and-coming middle-class neighbourhood. Upon my arrival, however, there were few signs left of this former prosperity. The roof and walls of the house were crumbling. It was dark and hot inside, with no electricity or running water, and the house mainly served as shelter at night and as a storage room for Roxana's few possessions: a table, chair, mattress, cooking utensils and clothes. To an extent, this state of affairs reflected that of other households in the area, and of Bairro Acordado as a whole. As civil war had taken its toll on Mozambique in the 1980s, living conditions in the neighbourhood had declined, while the population of civil servants and employees of state companies were also hit hard by the structural adjustment policies and wave of privatizations of the late 1980s and 1990s. But there were examples of families better able to weather these socio-economic and political changes, including among Roxana's neighbours. Roxana's household, although not the poorest, ranked among the poorer households of the area.

I would often find Roxana sitting on a chair in her yard, in the shadow of the mango tree in front of her house bordering the roadside, where she spent much of her days and proved an eager conversationalist. She recalled how, when she was born in 1978, her family had enjoyed a life of relative affluence. Her father worked as an assistant at the hospital, providing the family with a stable income, while her mother stayed at home to take care of Roxana and her older sister. They lived at her current house in Bairro Acordado, where her father's only son from an earlier marriage lived with them - the father had married Roxana's mother after his first wife had passed away. It had been a happy childhood, according to Roxana. There were long afternoons spent in the company of friends, as the children played games and explored the neighbourhood together. At other times, Roxana's father would take her and her sister along to work at the hospital where they would proudly sit and watch him operate the laundry machines.

The first setback came in the early 1990s. Roxana's stepbrother was imprisoned for theft in what would turn out to be the first of many criminal convictions in a life in and out of jail. Meanwhile, Roxana became pregnant. The child's father wanted little to do with the child, and while teenage pregnancies were not uncommon in Bairro Acordado, hers came at a bad time; because of budget cuts at the hospital, Roxana's father had been forced into early retirement, and, with her mother working as a cleaner to supplement his meagre pension, Roxana, who was fourteen years old, dropped out of school to raise her daughter. Several years later, she married another man named Flávio, with whom she had two children. But the marriage did not last, and she soon found herself back at her parents' house. Roxana married twice more and had four more children. With her last husband, looking for jobs, she set off for Niassa, the province west of Nampula, to cultivate tobacco. The objective was to earn enough money to buy 
their own house in Bairro Acordado. This they did, but a couple of years later, her husband surreptitiously sold the house and disappeared with the money to marry another woman in Niassa. Roxana moved in with her parents once again, where she helped her mother take care of her father, who by then was gravely ill. Unemployed, she relied on financial contributions from the fathers of her children and from suitors, as well as on occasional odd jobs to make ends meet, and she barely scraped by.

By the time I moved to Bairro Acordado, Roxana's household had just suffered another reversal. Nadine, Roxana's second daughter, aged fourteen, had run away from her father's house, which was located in another neighbourhood of Nampula City. Nadine had lived with Flávio and his new wife since his separation from Roxana, but did not get on well with her stepmother. One day, following an argument, she decided to leave for the house of her father's sister, who lived nearby. Flávio was furious when he found out. He suspected his sister of having used sorcery to kill their mother several years earlier, and thought that she and his daughter were now plotting to kill him. Speaking to Nadine, he accused her of being 'full of sorcery' and threatened to strike first, saying that he would go to a traditional healer (curandeiro) to have both her and his sister cursed. Upon hearing this threat, Roxana decided to intervene. She took in Nadine, reasoning that the distance would protect her daughter and prevent further escalation.

It soon became clear, though, that accommodating Nadine proved a challenge for Roxana. Her three youngest children were living with her and Nadine's arrival stretched her resources beyond what she could manage. To cope with her situation, Roxana solicited aid from people in her surroundings. Every morning at dawn, she would go on a hike through the area, fetching water from the well at the house of one neighbour, gathering plants at someone else's, asking for a bit of salt here and some charcoal and flour there. As described in the previous section, such requests are part and parcel of everyday life in Bairro Acordado. But whereas before Roxana had been able to offer small tokens of appreciation in return for the favours she received, the exchanges became more unidirectional after Nadine arrived to live with her. This put a strain on her neighbourly relations. Both she and her neighbours came to see each other as greedy and selfish. Roxana told me that one neighbour was a witch flying out at night to steal from other people. She indicated that another, an entrepreneur running a successful carpentry workshop, owed his wealth to a pact he had made with a genie. The genie would have promised to make him rich, but, in return, the man needed to sacrifice one of his relatives each year. The argument with Ali also took place around this time. As mentioned, it centred on the help offered by Rajah in occasionally providing food for Gerónimo, which Roxana rejected after she perceived that Rajah's children were bullying him. While Rajah considered the move ungrateful, Roxana interpreted the bullying behaviour as a sign of the children's unwillingness to share and of Rajah's household being ill-disposed towards hers. Her reference to sorcery in her exchange with Ali was an allusion to this, and Roxana had thought it better to keep her son away.

This was not the only time during fieldwork when Roxana was caught in the impossibility of balancing her various commitments towards her kin and neighbours. The same could be observed one year later when Roxana's mother suffered a stroke. Nadine had reconciled herself with her father by then and had moved back in with him, leading to a marked improvement in the relations between 
Roxana and her neighbours. The events following her mother's seizure, however, threatened to upset the balance once more. At the time of the stroke, attributed by Roxana to a sorcery attack by rural kin following a disagreement over inheritance, her mother had been living with her sister, Roxana's aunt, on the other side of Nampula City. She survived but could not speak or move until a healer treated her and she regained some of her abilities. A family meeting was held, and it was decided that the care for the mother was too much of a burden for Roxana's aunt, herself elderly. The mother, it was determined, was to move back to her late husband's house where Roxana would look after her. Roxana accepted the decision, but she was worried. Not only did having her mother back at the house mean extra expense; the healer treating her mother had also warned her that she must not have sex while her mother was recovering. Because the two were bonded as kin, the pressure generated by her sexual activity would transmit to the mother's heart and result in another stroke. This presented Roxana with a problem, because the gifts and money from her suitors had constituted one of the ways in which she had been able to get by.

Again, Roxana turned to her neighbours for help in dealing with her family situation. Again, it did not take long before irritations and tensions began to surface. At first, neighbours did not seem to mind the requests for assistance, which Roxana interspersed with complaints about her relatives and how they reneged on their promises to help out financially with the care of her mother. They understood, and many knew Roxana's mother from the time when she had lived at the house; some had gone to visit her at Roxana's aunt's place when they received news of her stroke. But after a while, behind her back, people began to express their disapproval of what they saw as Roxana's increasingly incessant pleas and selfish behaviour. There were no allegations of sorcery this time, but suspicion increased and this contributed to Roxana's social isolation. One neighbour accused Roxana of wanting to seduce and marry her husband. The neighbour living next door to Roxana - she was renting the house and had moved in six months earlier - said that Roxana had stolen plates and toys from her when she came to ask for fire, and constructed a bamboo fence between their yards. Roxana, for her part, resented her situation, and disparaged some of her neighbours for avoiding her. As fewer people came and sat down with her for a chat, she told me that they thought they were better than her and that they were selfish and had bad hearts.

These cycles of drawing closer and distancing underline the point made in the previous section about the detrimental influence of global economic forces on people's social relations and their ability to constitute themselves as moral persons. Roxana, when she grew up in Bairro Acordado, had been used to taking part in her neighbours' networks of assistance and exchange on a more or less equal basis. Years of downward mobility, however, caused in part by internationally prescribed neoliberal reforms, had compromised her capability to do so.

Consequently, every time her life hit a bump, her relations with her neighbours soured. What had been mutual interdependence looked set to become dependence by her on them; and her references to sorcery and occult accumulation articulated this tension. What this illustrates is the role of considerations of proximity and the fluidity of boundaries between the self, kin and strangers in furnishing sorcery fears in Nampula City. The reason why Roxana turned to her neighbours was 
that she wanted to avoid alienating herself from her kin. In the process, however, she ended up severing the rapport and connections she had built up with neighbours. This raised her fear of them, and vice versa.

\section{In God's hands}

This brings me to Rajah and the challenges she experienced in managing relations with her neighbours. Generally speaking, these were not nearly as tense as Roxana's. While Rajah was not an active participant in the social life of the area, she was on good terms with a number of neighbours and participated in their networks of assistance and exchange. They fetched water from her well, bought the pastries and maheyo (a non-alcoholic drink produced from maize flour and germinated malt) she sold from home, and she was a member of an informal savings group organized by neighbours. Her relatively harmonious relations with neighbours were also reflected in her stories of sorcery involving the people around her - or rather, in the lack of them. Nevertheless, a certain friction had begun to show at the time of Ali's confrontation with Roxana. This friction originated, just as in Roxana's case, in Rajah's strained relations with her kin, but it followed a very different logic.

Rajah was born and raised under similar circumstances to Roxana. Rajah was thirty-one years old, and so the two women were of roughly the same age, and, like Roxana, Rajah had been born in the neighbourhood. Her father had come to Nampula City from the coast to work for the railway company. Her mother hailed from one of the small islands off the coast of Nampula province. Civil war brought misfortune upon the family. In about 1986, when Rajah was six years old, her parents got divorced, and her mother took her and her sister to live in the nearby town of Monapo. Her mother was abducted by RENAMO a few years later, together with other relatives. The relatives escaped, but when the mother tried to flee as well, she was killed. A childless aunt living on Mozambique Island took Rajah and her sister in, and raised the two children. Rajah stayed in touch with her father, who, along with other colleagues, retired in the 1990s when the government mandated the downsizing of the railway company's workforce as part of its economic reforms. But she rarely saw him, and he died a couple of years after his retirement.

It was on Mozambique Island that Rajah had met her husband, Jafar, with whom she lived in Bairro Acordado. He was married with three children when they started seeing each other, but he left his wife to marry Rajah. The couple got off to a good start. Jafar worked as a mechanic and driver for a wealthy businessman on the island. During the country's civil war, Jafar's travels across northern Mozambique had provided him with lucrative opportunities to trade and earn extra income on the side, and this continued to be the case in the years following the 1992 General Peace Accords. Rajah remembered how he came home the day after they had first slept together and told her that their relationship was blessed; he had made a lot of money that day. However, their fortunes later went into reverse. Jafar's employer wanted to open a new business in Nampula City. He put Jafar in charge, and the couple moved to a company house in Bairro Acordado. When the business failed, Jafar lost his job. They had bought their current house as Jafar had found another job with a Portuguese businessman, 
but he quit a couple of years later when his employer implicated him in a customs scam and he spent a month in jail. Meanwhile, the couple had difficulties getting pregnant. Rajah suffered a number of miscarriages and their first child died when it was eighteen months old. After giving birth to their son, she became ill, and another baby was stillborn a couple of years later. Recently, however, the couple's prospects had been looking up again, at least financially. Jafar had found a job as a truck driver, transporting tree logs for a private business. One of the major clients was, ironically, the railway company. The company had profited from the recent boom of foreign investment in Mozambique to attract funds for the upgrading of its railroad network, and much of the construction work was outsourced to private contractors such as Jafar's employer.

Rajah's relations with her relatives were strained because of stories wrapped around sorcery. On Jafar's side of the family, there was an aunt living near the coast who was poor herself and would begrudge Jafar his luck. Rajah attributed both the failure of the business after she and Jafar had moved to Bairro Acordado and the time Jafar was jailed for his alleged involvement in the customs scam on a spell this aunt had put on him. The spell would also cause him to throw away his earnings on drinking and women rather than spend money on a future for himself and his family. About her own kin, Rajah said that her miscarriages and the death of their first child had resulted from sorcery attacks by the aunt who had raised her and her sister on Mozambique Island. She must have cursed Rajah by saying that, since she had not had any children herself, Rajah was to remain childless as well.

Rajah had tried various remedies to stop the sorcery attacks. Apart from seeking to maintain healthy kin relations, she had frequented a number of healers, each prescribing their own medicines and treatments. Recently, after her last miscarriage, Rajah had embarked on a novel strategy. She had left the local Sufi mosque where she had been a regular participant in ecstatic prayer (dikhr) sessions, and, together with Jafar, she had become a member of a reformist mosque. In signing up, the couple joined what has grown into a global phenomenon over the past few decades: the manifestation of Salafi-inspired Islamic reformism in Muslim contexts across the world (Kepel 1994; Roy 2002). The emergence of this brand of reformism has been relatively recent in northern Mozambique, but it has expanded rapidly, at the expense of historically prevalent Sufi-oriented forms of Islam (Bonate 2007; 2010; Declich 2013). ${ }^{5}$ The attraction it offered to Rajah and Jafar was its radical break with the Makhuwa notions of relatedness described earlier. Instead of defining the person in terms of interdependence

\footnotetext{
${ }^{5}$ As in other African countries (Brenner 1993; Kresse 2009; McIntosh 2007; Rosander 1997; Soares 2004), the growth of Islamic reformism in northern Mozambique is funded by international Islamic donors such as the Kuwait-based Africa Muslims Agency (AMA) and the Sudan-based Munazzamat al-Da'wa al-Islamiyya (MDI), whose scholarships for Islamic studies abroad and financial support for the construction of mosques and madrasas (Islamic schools) facilitate the incorporation of Mozambican Muslims into the Salafi faction of the umma (the global Muslim community). In adopting Salafi interpretations of Islam, Nampula City's Islamic reformists favour scripturalism and criticize alternative understandings of Islam as illicit innovations (bidah). Their aim is to return Islamic practice to the model provided by the first generations of Muslims, as well as for Muslims to take Islam as the primary frame of reference by which to negotiate every aspect of life (cf. Osella and Osella 2008: 248).
} 
and individual well-being as a function of people's social relations, Islamic reformism conceptualizes the self primarily in relation to God. It teaches that anything that happens in a person's life, whether good or bad, is part of God's design, and that people's sustenance is similarly predestined.

There is a great deal more to say about this, and I do so elsewhere (Laheij 2015), but let me confine myself here to two observations. First, reorientation towards God makes Islamic reformists feel comparatively less concerned than others in Nampula City about sorcery attacks. Similar to what has been written about the growth of Pentecostalism in Africa (Freeman 2012; Laurent 2001; Marshall-Fratani 1998; Maxwell 1995; Meyer 1999; van de Kamp 2016), beliefs and practices associated with Islamic reformism work to cut the social ties through which sorcery travels, and undermine feelings of guilt about the origins of wealth and success. In this, it is especially appealing to upwardly mobile urban migrants such as Rajah and Jafar who fear the ill will and envy of less fortunate others in their social surroundings. Reformism thereby also provides meaning. As Rajah explained to me, she felt relieved to know that hardship is ultimately part of the plan God has for her, and that if she falls victim to a sorcery attack, this is a trial from God for her to show her faith. Secondly, and paradoxically, however, as has been observed for Pentecostalism as well, involvement with Islamic reformism simultaneously heightens people's sense of vulnerability and concern with sorcery. In the case of reformism, this is partly because reformist beliefs do not rule out the existence of sorcery; reformists in Nampula City were quick to point out to me that Prophet Muhammad himself once fell victim to a sorcery attack. But it also follows from the demands Islamic reformism places upon its adherents, which stand in contradiction to prevalent Makhuwa norms of sociality. An example is the advice reformist leaders give their followers about staying away from non-Islamic funerals and not participating in the conspicuous consumption and sharing of food that is characteristic of Makhuwa funerary rites, including among Sufi Muslims. The advice is based on religious grounds, but others regard it as evidence of the stinginess and selfishness of reformists, which singles them out as targets for sorcery attacks, instead of reducing their fears.

Rajah had just begun to chart the parameters of this paradox when her stepson Ali quarrelled with Roxana. She was looking to find a middle ground between her various commitments, but, from what she told me, she perennially ended up feeling that she came up short. Her ambivalence in this regard only intensified when, nine months later, Jafar suffered an accident at work. One of his coworkers fell off the back of his truck and Jafar spent a week in jail, before his employer offered an advance on his salary to pay off police officials to drop the case. The couple sensed that the accident had resulted from another sorcery attack by Jafar's aunt. 'We need to demonstrate patience,' Rajah said, as she and her husband looked for comfort in their religion. While Jafar started attending prayers and Sunday classes at their reformist mosque more regularly, Rajah enrolled at the mosque's Islamic school (madrasa), something she told me she had been wanting to do but had previously not found the time for. Subsequently, she also changed her style of dress and asked Jafar to build a wall around their yard so that she would not have to worry about unrelated men seeing her when she took off her veil at home. Her neighbours reacted with indignation to these changes. Among themselves, they called her a show-off, 
and spoke disapprovingly of Jafar's jealousy in shielding his wife from the view of others. People started to avoid the couple, and eventually Rajah gave up her attempts to bridge the two worlds. In one of our last conversations, she described to me how she had two yards, her own and the madrasa, and that she only went out into the neighbourhood to move from one to the other. Her friends were now the other students at the madrasa, and if she needed a piece of burning coal to light her cooking fire, she asked them, or sent a child to the market to buy matches, rather than request assistance from the people living near her. She was aware of the dangers her isolation entailed. But, she affirmed with a resigned voice, her fate was in the hands of God.

The contrast between the cases of Rajah and Roxana is interesting. Compared with Roxana, Rajah had ultimately been better able to turn to her advantage the changes besetting Mozambique's economy and society during her life, thus providing for a measure of upward mobility and security. While this meant that she experienced less difficulty in participating in practices of neighbourly exchange and therefore suffered less from anxieties regarding their proximity, it also threw the differences in fortune between her immediate family and her rural kin into sharp relief. This became a cause of constant worry and concern for Rajah, who lived - more so than Roxana - in fear of the ill will of estranged relatives. Her response to these concerns was also different from Roxana's. While Roxana tweaked the margins of her relatedness with others, Rajah opted for a religious discourse that rejected such relatedness altogether. This freed her from the constraints and anxieties involved, but it also reinforced their salience. The latter highlights a point about modernity hitherto unexplored in this article: namely, that it comprises not only economic but also cultural forces, and that its cultural impact on local communities can equally become the subject of sorcery discourses. To the extent that Islamic reformism and its globally oriented rationalizing and individualist tendencies are 'modern', Rajah's case and her neighbours' accusations of greed and selfishness can be taken as evidence for this claim. Upon closer inspection, however, people's accusations were not driven by negative appraisals of modernity or Islamic reformism per se, but by their discontent with the effect these had on their mutual relations with Rajah; it turned her into a stranger. Just as in Roxana's case, then, modernity's potential for generating sorcery fears was mediated by considerations of social and physical proximity and the boundaries between the self, kin and strangers.

\section{Conclusion}

This article started with a description of a dispute between two neighbouring households in Bairro Acordado, those of Roxana and Rajah. The dispute culminated in a confrontation between Roxana and Rajah's stepson Ali, which was remarkable, I argued, for its explicit reference to sorcery and its public character. In analysing the events leading up to and following the confrontation, I showed that it brought together two women whose life paths diverged considerably, despite having been born in similar circumstances. One woman's life had been marked by a downward trajectory of socio-economic mobility, which had compromised her ability to engage in constructive relations with the people around her. At the time of the dispute, she was trying to protect her daughter from sorcery threats 
from her ex-husband, but ended up alienating herself from her neighbours. The other woman, meanwhile, had overcome a difficult childhood and attained a degree of security for herself and her family, only to find herself at the receiving end of the wrath and envy of her relatives living in the countryside. She attempted to cope with her fears by joining an Islamic reform movement. But, as with Roxana, these attempts resulted in estrangement from her neighbours. Taken together, the life histories of the two women show how challenging it is for urban migrants in northern Mozambique to establish themselves as moral persons and maintain their well-being. Achieving this requires that they invest equally in their relationships with kin and neighbours, but poverty, socioeconomic inequality and socio-cultural changes have made it increasingly difficult to manage this balance.

These findings have several implications for the anthropological literature on sorcery in Africa. The first implication relates, as discussed, to theories regarding the nature and prevalence of sorcery fears. Writing about urban contexts, Mitchell (1965) predicted in the 1960s that such fears would disappear with time. He based his prediction on a structural-functionalist analysis, according to which sorcery accusations derive from latent tensions in the positions people occupy in the social structure; fears of sorcery are therefore likely to occur between kin, not between city dwellers who are strangers to one another. A number of other authors (for example, Comaroff and Comaroff 1993; Geschiere 1997) have since argued, however, for a different interpretation. They point to the modernity of sorcery discourses, and conceptualize these as discursive frameworks through which Africans live and contest forces of production and accumulation. In this article, adding to recent calls for a renewed emphasis on kinship and linkages between macro- and micro-levels of social change, I have proposed a synthesis between the two strands of analysis, which focuses on questions of proximity. I have shown, in the context of Bairro Acordado, that prognoses about the demise of sorcery fears are indeed unwarranted. Compared with their rural counterparts, inhabitants of this neighbourhood do not feel less vulnerable to sorcery attacks; if anything, they feel more unsafe. Yet, this sense of vulnerability is not the direct result of their relative exposure to modernity and global economic and socio-cultural forces, even if these are referenced in people's sorcery narratives. Instead, it is an index of the difficulties residents of Bairro Acordado experience in Mozambique's current urban environment in extending their interdependence with strangers while simultaneously maintaining relations with rural kin. In that sense, Mitchell was correct to focus his analysis on questions of relatedness and social and physical distance.

The second implication for Africanist anthropology relates to the nexus of sorcery fears and urban migration. Several authors have pointed out, in response to theories such as Mitchell's about the inverse relation between sorcery discourses and urbanization, that urban areas are connected to rural ones in multiple ways, and that perceptions of vulnerability to sorcery attacks by kin do not vanish when people move to the city. Peter Geschiere and Francis Nyamnjoh (1998) found in Cameroon, for instance, that relations between urban migrants and their rural kin became a hotbed for sorcery rumours in the wake of the country's democratization. This was due to the combination of intimacy and socioeconomic inequality that marks these relations, to people's frequent dislocations between city and countryside, and to the increased importance of rural ties as 
political capital (see also Andersson 2002; Englund 2002). Meanwhile, other studies have refuted the assumption that living among strangers in cities reduces perceptions of sorcery. An example of this for the context of Mozambique comes from research by James Pfeiffer et al. (2007), in which they demonstrate that an influx of internally displaced refugees to Chimoio during the country's civil war, combined with deepening household inequality as a result of post-civil war structural adjustment economic reforms, exacerbated fears of crime and witchcraft in Chimoio's peri-urban neighbourhoods. The findings presented in this article show that both of these critiques apply to sorcery fears among urban migrants in Nampula City. However, my findings also indicate that an exclusive focus on either urban-rural linkages or proximity to strangers as factors in urban migrants' perceptions of sorcery is too narrow. These are interrelated and therefore need to be studied in conjunction.

\section{Acknowledgements}

The article is based on my doctoral research at the London School of Economics and Political Science. The research was supported by the LSE PhD scholarship programme, the Wenner-Gren Foundation for Anthropological Research, the British Institute in Eastern Africa, the Prins Bernhard Cultuurfonds, and the Central Research Fund, University of London. Earlier versions of this article were presented to the Africa Research Forum at Cambridge University, the Urban Kinship Workshop of the Nordic Africa Institute, and the Integration and Conflict Departmental Colloquium at the Max Planck Institute for Social Anthropology. I am grateful to the participants, as well as to Mats Utas, Jesper Bjarnesen, James Carrier and the reviewers for their valuable comments.

\section{References}

Andersson, J. A. (2002) 'Sorcery in the era of "Henry IV": kinship, mobility and mortality in Buhera District, Zimbabwe', Journal of the Royal Anthropological Institute 8 (3): 425-49.

Archambault, J. S. (2012) “"Travelling while sitting down”: mobile phones, mobility and the communication landscape in Inhambane, Mozambique', Africa 82 (3): 393-412.

Arnfred, S. (2011) Sexuality and Gender Politics in Mozambique: rethinking gender in Africa. Woodbridge: James Currey.

Ashforth, A. (2005) Witchcraft, Violence, and Democracy in South Africa. Chicago IL: University of Chicago Press.

Bertelsen, B. E. (2016) Violent Becomings: state formation, sociality, and power in Mozambique. New York NY: Berghahn Books.

Bonate, L. J. K. (2007) 'Roots of diversity in Mozambican Islam', Lusotopie 14 (1): 129-49.

Bonate, L. J. K. (2010) 'Islam in northern Mozambique: a historical overview', History Compass 8 (7): 573-93.

Bonhomme, J. (2012) 'The dangers of anonymity: witchcraft, rumor, and modernity in Africa', HAU: Journal of Ethnographic Theory 2 (2): 205-33.

Brenner, L. (1993) Muslim Identity and Social Change in Sub-Saharan Africa. London: C. Hurst and Co. 
Bubandt, N. (2014) The Empty Seashell: witchcraft and doubt on an Indonesian island. Ithaca NY: Cornell University Press.

Candea, M. and G. da Col (2012) 'The return to hospitality', Journal of the Royal Anthropological Institute 18 (S1): 1-19.

Ciscato, E. (2012) Introdução à Cultura da Área Makhuwa Lomwe. Lisbon: Fundação AIS.

Comaroff, J. and J. L. Comaroff (1993) Modernity and its Malcontents: ritual and power in postcolonial Africa. Chicago IL: University of Chicago Press.

Declich, F. (2013) 'Transmission of Muslim practices and women's agency in Ibo Island and Pemba (Mozambique)', Journal of Eastern African Studies 7 (4): 588-606.

de Matos, A. V. (1982) Provérbios Macuas. Lisbon: Ministério da Educação and Instituto de Investigação Científica Tropical.

Dinerman, A. (2006) Revolution, Counter-revolution and Revisionism in Postcolonial Africa: the case of Mozambique, 1975-1994. New York NY: Routledge.

Englund, H. (1996) 'Witchcraft, modernity and the person: the morality of accumulation in central Malawi', Critique of Anthropology 16 (3): 257-79.

Englund, H. (2002) 'The village in the city, the city in the village: migrants in Lilongwe', Journal of Southern African Studies 28 (1): 137-54.

Englund, H. and J. Leach (2000) 'Ethnography and the meta-narratives of modernity', Current Anthropology 41 (2): 225-48.

Evans-Pritchard, E. E. (1937) Witchcraft, Oracles, and Magic among the Azande. Oxford: Clarendon Press.

Freeman, D. (2012) 'The Pentecostal ethic and the spirit of development' in D. Freeman (ed.), Pentecostalism and Development: churches, NGOs and social change in Africa. London: Palgrave Macmillan.

Geffray, C. (1990) Ni Père, Ni Mère: critique de la parenté: le Cas Makhuwa. Paris: Éditions du Seuil.

Geffray, C. and M. Pederson (1986) 'Sobre a guerra na província de Nampula: elementos de análise e hipóteses sobre as determinações e consequências socio-económicas locais', Revista Internacional de Estudos Africanos 4-5: 303-18.

Geschiere, P. (1997) The Modernity of Witchcraft: politics and the occult in postcolonial Africa. Charlottesville VA: University Press of Virginia.

Geschiere, P. (2013) Witchcraft, Intimacy, and Trust: Africa in comparison. Chicago IL: University of Chicago Press.

Geschiere, P. and F. Nyamnjoh (1998) 'Witchcraft as an issue in the "politics of belonging": democratization and urban migrants' involvement with the home village', African Studies Review 41 (3): 69-91.

Hanlon, J. and T. Smart (2008) Do Bicycles Equal Development in Mozambique? Woodbridge: James Currey.

INE (2007) Censo 2007. Maputo: Instituto Nacional de Estatística (INE).

Kapferer, B. (2003) 'Sorcery, modernity and the constitutive imaginary: hybridising continuities' in B. Kapferer (ed.), Beyond Rationalism: rethinking magic, witchcraft and sorcery. New York NY: Berghahn Books.

Kepel, G. (1994) The Revenge of God: the resurgence of Islam, Christianity and Judaism in the modern world. Cambridge: Polity.

Kottak, N. C. (2002) 'Stealing the neighbor's chicken: social control in northern Mozambique'. PhD thesis, Emory University, Atlanta. 
Kresse, K. (2009) 'Muslim politics in postcolonial Kenya: negotiating knowledge on the double periphery', Journal of the Royal Anthropological Institute 15 (S2): 76-94.

Laheij, C. (2015) 'A country of trial: Islamic reformism, pluralism and dispute management in peri-urban northern Mozambique'. PhD thesis, London School of Economics and Political Science.

Laurent, P. (2001) 'The faith-healers of the Assemblies of God in Burkina Faso: taking responsibility for diseases related to "living together", Social Compass 48 (3): 333-51.

Lienhardt, G. (1951) 'Some notions of witchcraft among the Dinka', Africa 21 (1): 303-18.

Marshall-Fratani, R. (1998) 'Mediating the global and local in Nigerian Pentecostalism', Journal of Religion in Africa 28 (3): 278-315.

Martinez, F. L. (1989) 'O Povo Macua e a sua Cultura: análise dos valores culturais do povo macua no ciclo vital: Maúa, Moçambique 1971-1985. Lisbon: Ministério da Educação and Instituto de Investigação Científica Tropical.

Masquelier, A. (2008) 'Witchcraft, blood-sucking spirits, and the demonization of Islam in Dogondoutchi, Niger', Cahiers d'Études Africaines 68 (1-2): 131-60.

Maxwell, D. (1995) 'Witches, prophets and avenging spirits: the second Christian movement in north-east Zimbabwe', Journal of Religion in Africa 25 (3): 309 39.

Mbwiliza, J. F. (1991) A History of Commodity Production in Makuani, 16001900: mercantilist accumulation to imperialist domination. Dar es Salaam: Dar es Salaam University Press.

McIntosh, J. (2007) The Edge of Islam: power, personhood and ethno-religious boundaries on the Kenya Coast. Durham NC: Duke University Press.

Meyer, B. (1999) Translating the Devil: religion and modernity among the Ewe in Ghana. Edinburgh: Edinburgh University Press.

Mitchell, J. C. (1965) 'The meaning of misfortune for urban Africans' in M. Fortes and G. Dieterlen (eds), African Systems of Thought. London: Oxford University Press.

Niehaus, I. (2005) 'Witches and zombies in the South African Lowveld: discourse, accusations and subjective reality', Journal of the Royal Anthropological Institute 11 (2): 191-210.

Obarrio, J. (2014) The Spirit of the Laws in Mozambique. Chicago IL: University of Chicago Press.

Osella, F. and C. Osella (2008) 'Islamism and social reform in Kerala, South India’, Modern Asian Studies 42 (2-3): 247-57.

Pfeiffer, J., K. Gimbel-Sherr and O. J. Augusto (2007) 'The Holy Spirit in the household: Pentecostalism, gender, and neoliberalism in Mozambique', American Anthropologist 109 (4): 688-700.

Pitcher, M. A. (1996) Transforming Mozambique: the politics of privatization, 1975-2000. Cambridge: Cambridge University Press.

Pitt-Rivers, J. A. (1968) 'The stranger, the guest and the hostile host: introduction to the study of the laws of hospitality' in J.-G. Peristiany (ed.), Contributions to Mediterranean Sociology: Mediterranean rural communities and social change. Paris: Mouton. 
Rosander, E. E. (1997) 'Introduction: the Islamization of "tradition" and "modernity" in E. E. Rosander and D. Westerlund (eds), African Islam and Islam in Africa: encounters between Sufis and Islamists. London: C. Hurst.

Roy, O. (2002) Globalised Islam: the search for a new ummah. London: C. Hurst. Sanders, T. (1999) 'Modernity, wealth and witchcraft in Tanzania', Research in Economic Anthropology 20: 117-31.

Sanders, T. (2003) 'Reconsidering witchcraft: postcolonial Africa and analytic (un)certainties', American Anthropologist 105 (2): 338-52.

Sanders, T. (2008) Beyond Bodies: rainmaking and sense making in Tanzania. Toronto: University of Toronto Press.

Sanders, T. (2016) 'The pendulum swings', HAU: Journal of Ethnographic Theory 6 (1): 493-98.

Smith, D. J. (2001) "The arrow of God": Pentecostalism, inequality, and the supernatural in south-eastern Nigeria', Africa 71 (4): 587-613.

Soares, B. F. (2004) 'Islam and public piety in Mali' in A. Salvatore and D. F. Eickelman (eds), Public Islam and the Common Good. Leiden: Brill Publishing.

Sumich, J. (2015) 'The uncertainty of prosperity: dependence and the politics of middle-class privilege in Maputo', Ethnos 81 (5): 821-41.

van de Kamp, L. (2016) Violent Conversions: Brazilian Pentecostalism and urban women in Mozambique. Woodbridge: James Currey.

West, H. G. (2005) Kupilikula: governance and the invisible realm in Mozambique. Chicago IL: University of Chicago Press.

West, H. G. (2007) Ethnographic Sorcery. Chicago IL: University of Chicago Press.

Wilson, K. B. (1992) 'Cults of violence and counter-violence in Mozambique', Journal of Southern African Studies 18 (3): 527-82.

\begin{abstract}
Urban migrants in Nampula City, northern Mozambique, perceive themselves to be living in an environment where they are particularly vulnerable to sorcery attacks. Key to this sense of vulnerability are Makhuwa notions of matrilineal descent and relatedness, which work to locate sorcery fears in the interstices of two kinds of proximity, namely social and physical. Accordingly, people fear the translocal reach of the ill will of kin residing in the countryside, with whose well-being they remain connected regardless of the physical distance. Simultaneously, there are threats posed by urban neighbours who, due to their proximity in physical terms but separation in social terms, are considered dangerous. This article analyses practices of conspicuous exchange as one of the strategies urban migrants employ in coping with these anxieties. Specifically, it draws on the life histories of two women in one neighbourhood of Nampula City to explore the challenges they experience in meeting demands for material assistance from rural kin and urban neighbours. The analysis shows that their accounts of sorcery are structured by the difficulty of balancing such demands in a setting of poverty and socio-economic inequality. This finding has implications for anthropological theories of sorcery, misfortune and urban migration.
\end{abstract}




\section{Résumé}

Dans la ville de Nampula, dans le Nord du Mozambique, les migrants urbains se perçoivent eux-mêmes comme vivant dans un environnement dans lequel ils sont particulièrement vulnérables aux attaques de sorcellerie. Au cœur de ce sentiment de vulnérabilité se trouvent les notions makhuwa de la descendance matrilinéaire et de la connexité qui contribuent à situer les peurs de la sorcellerie dans les interstices de deux types de proximité, à savoir la proximité sociale et la proximité physique. C'est pourquoi les gens craignent la translocalité de la malveillance d'un parent résidant à la campagne, avec lequel ils restent connectés quelle que soit la distance physique. Simultanément, il existe des menaces posées par des voisins urbains qui, en raison de leur proximité en termes physiques mais de leur séparation en termes sociaux, sont considérés dangereux. Cet article analyse les pratiques d'échange ostentatoire comme une des stratégies que les migrants urbains emploient pour gérer ces anxiétés. En particulier, il s'appuie sur des récits de vie de deux femmes d'un quartier de Nampula pour explorer les difficultés qu'elles rencontrent face aux demandes d'assistance matérielle de parents ruraux et de voisins urbains. L'analyse montre que leurs récits de sorcellerie sont structurés par la difficulté à concilier ces demandes dans un contexte de pauvreté et d'inégalité socioéconomique. Cette conclusion a des implications pour les théories anthropologiques sur la sorcellerie, l'infortune et la migration urbaine. 